\title{
CULTURE
}

$\infty$

\author{
Lidia Kniaź \\ Maria Curie-SkŁodowska University (UMCS) Lublin \\ lidiakniaz@gmail.com
}

\section{Creative Use of Sound in the Cinematic Adaptation of The Great Gatsby}

\begin{abstract}
Sound design in film, described as "sound editing viewed artistically or aesthetically in terms of the shaping of the sound track in a film" (Buhler 2009, 430), is by definition a creative process demanding from its producers a great deal of inventiveness and aural imagination. Surprisingly, if one assumes that creativity is the key to successful sound design, it seems that very few contemporary soundtracks can be called successful at all. The goal of this paper is to examine the art of sound production in Baz Luhrmann's The Great Gatsby (2013) in terms of its creative use of sound. The analysis will focus on scenes from the movie in which sound does more to the overall impression and interpretation of the film than merely confirm the story that is told. Meanings of sound sequences in The Great Gatsby will be examined by in juxtaposition with selected plot elements. The sound in Luhrmann's production is creative mostly because it serves unique and unexpected functions that make it different from what seems to be the usual cinematic practice. It correlates with images in an innovative way, plays with diegetic vs. non-diegetic distinction (which is applied in the score analysis), and creates certain sonic spaces through skillful editing. All these "subtle-but-meaningful cinemusical details" (Holbrook 2011, 252) allow for interpreting the film in contemporary contexts.
\end{abstract}

Keywords: soundscape, ambidiegesis, score, micro sonic space.

The Great Gatsby (2013) is a cinematic adaptation of F.S. Fitzgerald's novel of the same title. The Jazz Age story of the eponymous nouveau riche was directed by Baz Luhrmann. Even though both the film and its soundtrack received mixed-to-negative reviews, the music and sound editing in The Great Gatsby were praised by The Association of Motion Picture Sound Editors, which in 2014 awarded the film in Best Sound Editing: Music in a Feature Film category (Tapley). 
Luhrmann's innovative approach to sound in film, in this case heavily depending on urban hip-hop, cannot pass unnoticed since, according to Michel Chion (1994, 5), it is sound that is capable of providing the film with "added value," defined as

the expressive and informative value with which a sound enriches a given image so as to create the definite impression, in the immediate or remembered experience one has of it, that this information or expression "naturally" comes from what is seen, and is already contained in the image itself.

However, this "added value" was understood in a broader sense by the producers of The Great Gatsby as sound does here more than just enhances onscreen image. Taking into consideration the fact that Luhrmann's adaptation has relatively few departures from the original, and even when it does, they are not pivotal plot elements, the film can be described as bold in terms of its soundtrack. One of the main functions of sound is to help achieve the so-called reality effect, but the soundtrack of The Great Gatsby is different in this respect. Even though The Great Gatsby is an adaptation, a "form of repetition, but repetition without replication" (Hutcheon 2012, 7) its producers have not chosen period music in constructing the soundtrack in order to remain more faithful to the reality described in the novel. Undeniably, music in The Great Gatsby is filled with Charleston "vibe" but creating the soundtrack with a strong jazz influences done for a reality effect was not the main aim of Gatsby's sound designers. Like Romeo and Juliet (1996), also directed by Luhrmann, The Great Gatsby's soundtrack is not in the background. Jay Z, the film's music executive producer, claims that "the music became a character" (“"The Great Gatsby' Soundtrack Boasts All-Star Lineup"). Seemingly inadequate, or even incongruent, the soundtrack in The Great Gatsby allows us to interpret the film in modern contexts. In a broader sense, sound in The Great Gatsby is creative, because it bridges modern times and the Roaring Twenties, opening new ways of interpreting the film. The role of sound in Luhrmann's production is, most predominantly, to attract the audience's attention to how similar many processes and phenomena of the 1920s are to contemporary ones. Therefore, the film does not merely re-tell a period story - it tells the audience something about their world. At the same time, The Great Gatsby provides examples of the excellent use of sound in terms of combining visuals with sound.

In this paper I am going to analyze selected scenes in which sound has certain innovative functions, "adds" to the film, lives on its own, and does not simply accompany the visuals. Apart from the main creative function of sound in The Great Gatsby, which is that of a non-period soundtrack being a tool that makes the audience notice parallels between two decades, the sound plays many other roles that are observable mostly on a smaller scale but are significant to the overall perception of the movie. These nonconventional functions of sound are connected more with the technical side of the film production rather than the emerging meaning of the soundtrack as such. 
Nonetheless, they can be interpreted in relation to the general overtone of The Great Gatsby's latest adaptation. For the purposes of this paper, I will divide the creative functions of sound design into four sub-groups and provide examples in each of the categories. At the same time I stress the fact that the grouping I distinguish is only my subjective classification and I realize that the provided examples may fall into more than one category concurrently.

In the first place, the soundtrack in The Great Gatsby does not follow the reality effect function of sound in film. Interestingly, the opening of the film resembles the first motion pictures. This is in line with the viewers' expectations as the film is based on a novel from the1920s. Only after the first few minutes of The Great Gatsby does the audience realize that it is not jazz but modern sound tinted with jazz that is going to accompany the movie. It is the track by Jay $\mathrm{Z}$ and Kanye West, "No Church in the Wild," in the third minute of the film that frustrates the expectations of the audience for the first time. On the other hand, the choice of this urban song collated with the retro image seems to be deliberate. Even though the hip-hop song can be considered as incongruous, it is used in this scene to convey the atmosphere of the City which is, indeed, lacking in harmony and full of contradictions.

The second example of Gatsby's creative sound design are numerous innovative correlations between image and sound that remain unheard for most viewers. The first instance appears between 21:29-22:52 minutes of the movie, during one of the parties at Buchanan's apartment in New York. The scene is accompanied by a melodic jazz line with the dominant tambourine groove at the beginning which with time blurs into a steady sound of bowed strings, in this case constituting the rhythm section, and some sort of a closed crash cymbal playing the role of a hi-hat ${ }^{1}$ in the melody. The dynamic line of the string section is relatively fast, the tempo seems to accelerate with time; however, this acceleration is an illusion achieved by the accumulation of sounds. The arrangement of this part of the score is formed by the string section with an occasional entrance of other instruments, such as a trilling trumpet sound in 22:23 or a soprano saxophone at the end of the scene.

In line with one of the most common functions of film music, sounds accompanying the party in New York aim at enhancing the drama present in the scene. Interestingly, in this scene metal hammers - objects which are not regarded as musical instruments - contribute to the tone of the orchestral score. After Tom slaps Myrtle in the face, Nick leaves the apartment and goes out onto the balcony. What follows this fragment is a crane shot employed in order to draw viewers' attention to the image of the working men. The unsettling beat of their hammers is skillfully arranged with the sound of the score from previous shots. Before Tom's violent outburst, the atmosphere seems to get more tense with each beat per minute but only after Tom's act of violence does the tension in the room release. Instead of numerous blending instrumental tones, the audience hears only one of them, namely the abovementioned hi-hat, which resembles

Hi hat is a pair of foot-operated cymbals that form part of a drum kit. 
the metallic sound of a hammer. The viewers are not sure whether they hear the sound of a hammer or a crash cymbal from the preceding melodic section. Consequently, the boundaries between what is an element of the orchestral score and what is just an inserted Foley sound ${ }^{2}$ are blurred.

In this scene, the sound is crucial, not only because it enhances the drama but also because it expresses the atmosphere of a given space. For instance, Buchanan's apartment is a place associated with louder sounds, for instance with the sound of bed springs squeaking, or music played at parties, but it is outside the apartment block that the audience can hear genuine city sounds, such as a trumpet player on the balcony, or the hammering of men working even in the dead of night. As previously stated, sound in film helps to create the atmosphere ascribed to certain spaces. Thus, the sound of hammers, for instance, viewed as a metaphor of manual laborers, can be read as an inseparable element of city soundscape.

Another example of the creative sound-image correlation is visible in a scene between 14:30 and 14:35, when Nick Carraway is at a doctor's office and in his mind's eye he sees the Valley of Ashes. His memories about the place are projected onto blank pages of the book he is to write. While he recalls the hammering laborers, the sound of the train whistle is heard. which is connected with the place he refers to but at the same time the sound is asynchronous to the image presented on screen. The interesting thing about this disparity between sound and image is that is causes some sort of lack of fidelity - what is heard does not correspond with what is seen. The audience does not expect the sound of the train whistle when they know the characters are in the closed, limited space of a doctor's office.

Finally, one of the most interesting examples of sound-image relationships is the leitmotif of the sharp violin sound appearing alongside the symbolic green light. The light represents Gatsby's dream and his hopes for the future but the tone of the sound is far from evoking positive connotations. The reappearing high-pitched fragment of the score creates an atmosphere of uncertainty, misery and melancholy, so the metaphor of the green light is, in fact, something elusive, or rather unreachable in the long run. In Luhrmann's adaptation of The Great Gatsby the "emblematic" green light is given "musical dimension" (Chagollan), which, undoubtedly, is an "added value" (Chion 1994, 5) in the interpretation of the film.

The third broad area in which the soundtrack in The Great Gatsby may be viewed as creative is its editing. For instance, in one of the scenes (01:27:09) there is a sound from the score, which, in a sense, plays the role of an object which does not appear on screen. This clock-like ticking sound from The XX's "Together" song can be interpret-

2 Foley is defined as a "sound effects technique used for synchronous effects or live effects." The technique was named after Jack Foley, a sound designer from Universal Studios. Foley sounds are added in postproduction to enhance the reality effect in film. Foleying is a means of supplying the subtle sounds that are often lost in production. They include sounds such as the rustling of clothing, snow crunching, footsteps, or door squeak.

("Foley Artistry") 
ed as a factor creating the atmosphere of anticipation - Gatsby is waiting for Daisy's decision. In a way, this sound is also like a time bomb ticking, which is a sign that something tragic will soon happen. It can be argued whether the choice of this particular fragment was a purposeful action or not, but it undoubtedly intensifies the emotions of the audience over the scene and indicates complex layers of soundtrack editing in the movie. Another example of similar artistry in terms of image and sound editing can be observed in the way in which the contemporary soundtrack is skillfully mixed not only with the orchestral score, which is typical of Hollywood movies, but also with the original 1920s jazz tracks. These advanced editing techniques pertain both to mixing of the compilation soundtrack in The Great Gatsby and to the diegetic sounds of jazz musicians present onscreen at Gatsby's parties.

There is no denying that, despite its contemporary pop/hip-hop vibe, The Great Gatsby's soundtrack is rooted in the original 1920s sound. However, the craft of the producers is observable mostly in the smooth transitions between the diegetic and nondiegetic sounds, which in the case of this particular film are difficult to separate. ${ }^{3}$ Interestingly, Morris Holbrook $(2011,29)$ in his book Music, Movies, Meanings, and Markets: Cinemajazzamatazz coins the term "ambi-diegesis" which seems to be relevant as a marker of the fuzzy relations between diegetic and nondiegetic sound on screen in The Great Gatsby (29). Also, he addresses the issue of ambi-diegetic sounds in his essay entitled "The Ambi-Diegesis Of 'My Funny Valentine." Holbrook (2011, 48) described the idea as follows:

As various observers have noted, however, many uses of music in films blur the boundaries of the diegetic/non-diegetic distinction or fall between the extremes of these polarities (Altman, 1987; Chion, 1994; Kassabian, 2001; Smith, 1998; see also Buhler, et al., ed., 2000). One such possibility, not specifically emphasized by others, involves the use of film music in a manner that I would characterize as ambi-diegetic (Holbrook, 2002). Here, I refer to a cinematic situation in which a character actually performs a tune or song on camera (within the image) in a way that adds depth to that character by forming persona-related associations, that elaborates on thematic aspects of the plot, or that advances relevant symbolic identifications so as to enrich the meaning of the scene (dramatic development).

Ambi-diegesis in The Great Gatsby is employed, for instance, in the scenes in which Nick attends one of the parties in Buchanan's secret apartment in New York. The audience notices a jazzman playing the trumpet on the balcony. At first glance, the trumpeter appears to be just a silent, minor character attending the party in some

3 Diegetic sound is the sound whose source is visible on screen. It can take the form of voices of the characters, source music (that is "played" within screen limits), and sound effects. Nondiegetic sound (also called "commentary") is the sound that comes from a source "outside the story world" (Bordwell 2010, 284). Mood music, the voice of the narrator, or sound effects added for the dramatic effect are the examples of nondiegetic film sound. 
indirect way. Nevertheless, he contributes to the city's soundscape as the sound of the trumpet is one of the elements constituting the atmosphere of the City. His onscreen sound adds to the abovementioned "depth," since the character is not just a random man but a symbol of the urban space. The single jazz player, not accompanied by a large orchestra, as he would be during the parties at Gatsby's, appears only in the City. His presence is "subtle-but-meaningful" (Holbrook 2011, 252) and what he does is "small-but-significant" (246). Interestingly, the sound of the trumpet is brilliantly edited into a song accompanying the scene, namely "Who Gon' Stop Me" by Kanye West and Jay Z. As a result, both the song and the party scene as a whole can be interpreted quite differently because the trumpet sound here is rather plaintive and nostalgic. The sound of jazz changes the mood of the scene, which no longer depicts cheerful and carefree time spent in New York.

The last form of nonconventional and creative use of sound in The Great Gatsby is its capability of creating micro-sonic spaces in the soundtrack and in onscreen images. In the scene in which Gatsby is telling Nick "the God's truth" (The Great Gatsby 2013 Movie Script 14) about himself while driving through the Queensboro Bridge, the men are passing a car with a group of partying African-Americans and a white chauffeur behind the wheel. What is interesting, at the very moment Nick is looking at the car, the sound in the film changes diametrically - from ragtime jazz to a contemporary hip-hop song, just in time to blur into an orchestral score melody. The illusion, which can be viewed as a brief time travel for both Nick and the audience, is stopped by a snap of fingers. It can be said that this snap moment helps the score music reappear and blend smoothly with the rest of the soundtrack. Interestingly, the song present in this fragment is a well-known car and party track "Izzo (H.O.V.A)" by Jay Z. The short period of time with the camera focusing on the group of African-Americans with accompanying hip-hop sound can be compared to a typical rap music video, but this is not the main function that this fragment serves. A far more important aspect is that the scene creates a unique kind of micro-sonic space for the car. It makes the characters and viewers stop for a moment in order to feel and notice the complex, often confusing, nature of the City where different spaces and its members are experiencing constant interactions. The car as a limited space is capable of having an atmosphere different from that of the environment it is surrounded by, it has the "vibe" which is timeless and is ascribed to this particular place.

In classical Hollywood cinema sound was viewed as secondary to the image, since it often "remained unnoticed" (Bordwell 2010, 269). However, in the case of The Great Gatsby, it seems impossible not to refer to sound on numerous levels as the film is so creative in this respect. The producers must have taken into account the fact that their inventive soundtrack design techniques would be exposed to harsh words of criticism. On the other hand, each attempt to make an adaptation of a classic novel is bound to be criticized in one way or another, which is why, in my view, Luhrmann opted for all-ornothing approach to sound design. His "modern hip-hop layered over ragtime piano" (Seitz) is a mixture which esthetically can be called a complete failure (Mejia) but it is 
actually a well-planned "successful failure" since the soundtrack allows the audience to both follow the plot despite the incongruous sound, and notice that this experimental mash-up is employed not without reason. In conclusion, the producers of The Great Gatsby have seen to all "subtle-but-meaningful cinemusical details" (Holbrook 2011, 252) which, undoubtedly, add to the value of the film and make it something far more creative than the majority of often-too-imitative cinematic adaptations.

\section{References}

Bordwell, David, and Kristin Thompson. 2010. Film Art: An Introduction. 9 edition. New York: McGraw-Hill Higher Education.

Buhler, James, David Neumeyer, and Rob Deemer. 2009. Hearing the Movies: Music and Sound in Film History. New York: Oxford University Press.

Chagollan, Steve. 2013. “"Gatsby's' Great Music Collection.” Variety, April 17. http://variety. com/2013/film/features/gatsby-1200370682/.

Chion, Michel. 1994. Audio-Vision: Sound on Screen. 14th edition. New York: Columbia University Press.

"Foley Artistry." 2016. Film Sound. Accessed May 26, 2016. http://filmsound.org/foley/.

Holbrook, Morris. 2005. "The Ambi-Diegesis Of 'My Funny Valentine."' In Pop Fiction: The Song in Cinema, edited by Matthew Caley and Steve Lannin, 48-62. Bristol, UK ; Portland, Or: Intellect Ltd.

Holbrook, Morris. 2011. Music, Movies, Meanings, and Markets: Cinemajazzamatazz. New York: Routledge.

Hutcheon, Linda. 2012. A Theory of Adaptation. 2nd edition. London; New York: Routledge.

"Jay-Z Biography." 2015. Rolling Stone. Accessed August 24, 2015. http://www.rollingstone. com/music/artists/jay-z/biography.

Jones, Michael. 2008. "Baz Luhrmann Eyes “Great Gatsby.” Variety, December 18. http://variety.com/2008/film/markets-festivals/baz-luhrmann-eyes-great-gatsby-1117997638/.

Luhrmann, Baz. 2013. The Great Gatsby. Warner Bros.

Mejia, Paula. 2013. “Gatsby Soundtrack Beats On, Borne Back Ceaselessly Into Failure.” Time, May 10. http://entertainment.time.com/2013/05/10/gatsby-soundtrack-beats-on-borne-backceaselessly-into-failure/.

"Prohibition | United States History [1920-1933]." 2015. Encyclopedia Britannica. Accessed August 24, 2015. http://www.britannica.com/event/Prohibition-United-States-history-1920-1933.

Seitz, Matt Zoller. 2013. “The Great Gatsby Movie Review (2013).” Roger Ebert. May 8. http:// www.rogerebert.com/reviews/the-great-gatsby-2013.

Tapley, Kristopher. 2014. “'Gravity,' 'Captain Phillips' Lead MPSE Golden Reel Sound Editing Award Winners." HitFix. February 17. http://www.hitfix.com/in-contention/2014-mpsegolden-reel-awards-winners. 
Pobrane z czasopisma New Horizons in English Studies http://newhorizons.umcs.pl Data: 26/04/2023 16:05:24

"The Great Gatsby (2013) Movie Script.” 2015. Springfield! Springfield! Accessed August 24, 2015. http://www.springfieldspringfield.co.uk/movie_script.php?movie=the-great-gatsby.

“"The Great Gatsby' Soundtrack Boasts All-Star Lineup.” 2013. Business Wire. April 4. http:// www.businesswire.com/news/home/20130404005754/en/\%E2\%80\%9CThe-Great-Gatsby\%E2\%80\%9D-Soundtrack-Boasts-All-Star-Lineup\#.VdrHliWqqko. 